\title{
PENGARUH SUBSTITUSI PAKAN KOMERSIAL DENGAN PAKAN KONSENTRAT BUATAN TERHADAP PERFORMANS ITIK UMUR 2 MINGGU
}

\author{
I Made Adi Sudarma1, Maulana Bahasuan ${ }^{2}$ dan Marselinus Hambakodu ${ }^{3}$ \\ Program Studi Peternakan, Universitas Kristen Wira Wacana Sumba, Jl. R. Soeprapto No 35 Waingapu, \\ Telp. (0271) 593156, Koresponding author, email: made@unkriswina.ac.id \\ Program Studi Peternakan, Universitas Kristen Wira Wacana Sumba, Jl. R. Soeprapto No 35 Waingapu, \\ Telp. (0271) 593156, email: maulanabahasuan92@yahoo.com \\ Program Studi Peternakan, Universitas Kristen Wira Wacana Sumba, Jl. R. Soeprapto No 35 Waingapu, \\ Telp. (0271) 593156, email: marsel.hambakodu@unkriswina.ac.id
}

\begin{abstract}
Abstrak
Penelitian ini bertujuan untuk mengetahui pengaruh substitusi pakan komersial dengan pakan konsentrat buatan terhadap bobot hidup, pertambahan bobot badan harian dan konversi ransum ternak itik umur 2-10 minggu. Penelitian ini menggunakan itik sebanyak 36 ekor dan ditempatkan dalam 12 kandang yang masing-masing berukuran 1x1 meter. Penelitian ini menggunakan Rancangan Acak Lengkap (RAL) dengan 3 perlakuan dan 4 ulangan. Perlakuan yang dicobakan adalah pakan komersial $\mathrm{BR}_{2} 100 \%\left(\mathrm{P}_{0}\right)$, Pakan komersial $\mathrm{BR}_{2} 50 \%$ + Pakan konsentrat buatan 50\% $\left(\mathrm{P}_{1}\right)$ dan Pakan konsentrat buatan $100 \%\left(\mathrm{P}_{2}\right)$. Hasil penelitian menunjukkan bahwa tidak terdapat pengaruh yang nyata terhadap variabel bobot hidup ternak itik umur dua minggu sampai 10 minggu (1.497,08 gram/ekor/hari) dan pertambahan bobot badan harian ternak itik (21,50 gram/ekor/hari) namun memberi pengaruh nyata terhadap konversi ransum untuk setiap perlakuan ( $\mathrm{P}_{0}: 4,85, \mathrm{P}_{1}: 5,52$ dan $\left.\mathrm{P}_{2}: 6,63\right)$. Disimpulkan bahwa pakan konsentrat buatan $\left(\mathrm{P}_{2}\right)$ dapat mengganti $100 \%$ pakan komersial $\mathrm{BR}_{2}$ dengan nilai konversi ransum yang lebih tinggi namun diimbangi dengan harga yang lebih ekonomis.
\end{abstract}

Kata kunci : itik penggemukkan, konversi ransum, pakan komersial, pakan konsentrat

\begin{abstract}
This study aims to determine the effect of substitution of commercial feed with artificial concentrate feed on live weight, daily body weight gain and ration conversion of ducks aged 2-10 weeks. This study used 36 ducks and placed in 12 cages, each measuring $1 \times 1$ meter. This study used a Completely Randomized Design (CRD) with 3 treatments. and 4 replicates. The treatments tested were $100 \%$ BR2 commercial feed $\left(P_{0}\right), 50 \%$ BR2 commercial feed $+50 \%$ artificial concentrate feed $\left(P_{1}\right)$ and $100 \%$ artificial concentrate feed $\left(P_{2}\right)$. The results showed that there was no significant effect on live weight variables of ducks aged two weeks to 10 weeks (1,497.08 grams/head/day) and daily body weight gain of ducks (21.50 grams/head/day) but gave significant effect on ration conversion for each treatment $\left(P_{0}: 4.85, P_{1}: 5.52\right.$ and $\left.P_{2}: 6.63\right)$. It was concluded that artificial concentrate feed (P2) could replace $100 \%$ of commercial BR2 feed with a higher ration conversion value but offset by a more economical price.
\end{abstract}

Keywords: fattening ducks, feed commercial, feed concentrate, feed conversion

\section{PENDAHULUAN}

Populasi itik di Kabupaten Sumba Timur sebesar 2.873 ekor atau $0,83 \%$ dari total populasi ternak itik di NTT (Dinas Peternakan NTT, 2016). Itik berpotensi tinggi untuk dikembangkan sebagai ternak produksi telur dan daging. Permintaan produk ternak itik cukup tinggi di masyarakat baik produk telur itik sebagai olahan makanan seperti telur asin maupun permintaan produk daging itik seperti itik betutu. Penurunan populasi ternak itik di Sumba Timur selama 5 tahun terakhir di sebabkan oleh manajemen pemberian pakan yang kurang efektif. Sebagian besar masyarakat di kawasan pertanian bergerak dalam pemiliharaan ternak itik karena memiliki beberapa kelebihan yaitu masa 
Agrisaintifika

Jurnal Ilmu-Ilmu Pertanian

Vol. 5, No. 2, 2021

pemeliharaanya singkat, tahan terhadap hama penyakit, serta harga DOD (Day Old Duck) yang relatif lebih murah. Kendala untuk mempersiapkan produk daging itik perlu persiapan manajemen pemeliharaan yang baik untuk mendukung kebutuhan protein daging. Guna mengatasi kendala tersebut perlu adanya perbaikan kualitas ransum. Selain itu, juga perlu adanya upaya untuk meningkatkan efesiensi penggunaan ransum pada ternak itik masa pertumbuhan umur 2 minggu hingga panen. Manipulasi ransum adalah cara untuk meningkatkan efisiensi ransum guna meningkatkan kemampuan produksi. Periode starter merupakan masa yang penting untuk perkembangan fisiologis saluran pencernaan. Pemberian ransum yang berkualitas dapat meningkatkan kecernaan nutrient dan performans produksi ternak itik. Menurut Puvanendran et al., (2003) menyatakan bahwa umumnya, tingkat konsumsi pakan yang tinggi mengarah ke tingginya bagian dari bahan makanan yang melalui saluran pencernaan, daya cerna rendah dan rendahnya penyerapan nutrisi. Daya cerna dan penyerapan nutrisi yang rendah maka akan berkorelasi prositif terhadap konversi pakan yang nilainya akan lebih tinggi.

Konversi ransum dapat dijadikan sebagai patokan penilaian pada sebuah ransum yang dapat dikonsumsi dan diolah menjadi jaringan tubuh dalam bentuk bobot badan ternak (Ambara et al., 2013). Untuk melihat kemampuan ternak mengkonversi pakan menjadi produk terutama daging adalah bahwa penggunaan ransum semakin efisien apabila FCR semakin kecil, dan dikatakan buruk jika FCR nya semakin besar (Anggraini et al., 2017).

Pakan konsentrat buatan memiliki keunggulan yakni kandungan nutrien yang hampir sama dengan pakan komersial BR2 dan NRC 1994 tentang kebutuhan nutrisi itik lokal umur 2-7 minggu. Salah satu cara yang di tempuh untuk meningkatkan bobot hidup dan konversi ransum yang baik pada ternak itik yaitu dengan cara manajemen pemberian pakan yang baik dan kualitas nutrisi ransum yang baik. Purba dan Ketaren (2011) menyatakan bahwa penggunaan pakan yang tidak efisien pada itik petelur maupun pedaging dapat diakibatkan oleh beberapa faktor yakni faktor genetik/bibit, banyaknya pakan tercecer dan kandungan gizi pakan yang tidak sesuai kebutuhan. Menurut Ketaren (2007) menyatakan bahwa hasil penelitian pada ternak itik selama 8 minggu pemeliharaan mengkonsumsi pakan dengan kandungan dedak padi tinggi (72,5\%) memililki nilai konversi pakan sebesar 4,175,58 dengan PBB sebesar 1.265-1.409 gram/ekor. Sistem pemeliharaan ternak itik lokal oleh peternak di Kabupaten Sumba Timur masih bersifat semi intensif dengan pakan utama berupa dedak padi dan jagung perlu dikembangkan dan diteliti sehingga diketahui potensi konsumsi pakan dan nilai konversi ransumnya apabila diberikan pakan konsentrat dengan level yang berbeda.

Berdasarkan permasalahan diatas maka perlu dilakukan penelitian tentang pemberian pakan konsentrat buatan dengan level berbeda terhadap konsumsi pakan, $\mathrm{PBBH}$, bobot hidup dan konversi ransum ternak itik umur dua minggu.

\section{BAHAN DAN METODE}

\subsection{Bahan}

Bahan yang digunakan dalam penelitian ini meliputi polar, jagung, dedak dan mineral. Penelitian ini menggunakan 36 ekor ternak itik dimana setiap unit percobaan/kandang terdapat 3 ekor ternak itik. Alat yang digunakan berupa 12 unit kandang ukuran $1 \times 1 \mathrm{~m}$, tempat makan dan tempat minum.

\subsection{Metode}

Dalam penelitian ini digunakan metode rancangan acak lengkap (RAL) dengan 3 ulangan dan 4 perlakuan sehingga terdapat 12 unit percobaan. Perlakuan yang diberikan : Pakan komersial $\mathrm{BR}_{2} \quad 100 \%\left(\mathrm{P}_{0}\right)$; Pakan komersial $\mathrm{BR}_{2} 50 \%+$ Pakan konsentrat 
Jurnal Ilmu-Ilmu Pertanian

Vol. 5, No. 2, 2021

Sudarma, et al. 2021

buatan 50\% $\left(\mathrm{P}_{1}\right)$; dan Pakan konsentrat buatan $100 \%\left(\mathrm{P}_{2}\right)$.

\section{HASIL DAN PEMBAHASAN}

\section{Bobot Hidup Ternak Itik}

Bobot hidup adalah bobot badan yang di hasilkan pada awal umur dua minggu dan bobot badan yang di hasilkan pada akhir umur 10 minggu.

Tabel 1. Bobot hidup ternak itik umur 10 minggu

\begin{tabular}{ll}
\hline Perlakuan & Rata-rata (gram/ekor) \\
\hline P0 & $1.705,00 \pm 81.36$ \\
P1 & $1.667,17 \pm 85.52$ \\
P2 & $1.497,08 \pm 89.92$ \\
\hline
\end{tabular}

Berdasarkan hasil analisis ragam pakan perlakuan tidak berbeda nyata $(P>0,05)$ terhadap bobot hidup ternak itik umur 10 minggu. Hal ini disebabkan bahwa pakan konsentrat buatan dengan level protein kasar sebesar $15 \%$ dan $\mathrm{BR}_{2} \quad 19,5 \%$ mempunyai pengaruh yang sama terhadap pertambahan bobot hidup ternak itik selama dua bulan masa pemeliharaan tetapi memiliki tingkat konsumsi yang berbeda. Hasil penelitian bobot hidup awal ternak itik umur dua minggu yang di gunakan dalam penelitian ini dari berat terendah 39,05 gram/ekor hingga berat tertinggi 60,95 gram/ekor. Berdasarkan penelitian ini terdapat kenaikan bobot hidup ternak itik umur 10 minggu sebesar 1.623,08 gram selama proses pemeliharaan delapan minggu. Hasil penelitian menunjukan bobot hidup ternak itik tertinggi mencapai bobot 1.705,00 gram/ekor. Hasil penelitian ini juga menunjukan bahwa itik yang mendapatkan perlakuan pakan $\mathrm{P}_{2}$ (Pakan konsentrat buatan 100\%) memiliki rataan bobot hidup umur 10 minggu terendah sebesar 1.497,08 gram/ekor. Perlakuan pakan $\mathrm{P}_{0}, \mathrm{P}_{1}$ dan $\mathrm{P}_{2}$ selama delapan minggu tidak jauh berbeda. Penggunaan pakan konsentrat memiliki kandungan nutrient yang hampir sama dengan $\mathrm{BR}_{2}$ sehingga dapat dijadikan pakan

penggemukan ternak itik. Penggunaan ransum dengan level protein $15 \%$ ini tidak jauh berbeda dengan hasil penelitian Purba dan Ketaren (2011) dimana rataan bobot hidup itik pada umur 8 minggu berkisar antara $1.425,72$ hingga $1.500,72$ gram/ekor.

Bobot hidup merupakan salah satu sifat yang memiliki nilai ekonomis dan bersifat kuantitatif yang dikendalikan oleh banyak gen (Stansfield, 1983). Prasetyo et al. (2005) mengatakan bahwa dengan adanya perbaikan manajemen pemeliharaan, dapat meningkatkan bobot badan itik yang dicapai lebih tinggi. Peningkatan bobot badan sangat penting dan berkaitan erat dengan produksi daging.

\section{Pertambahan Bobot Badan Harian}

Pertambahan bobot badan harian adalah bobot badan awal dalam penelitian diukur pada saat akan diberikan perlakuan. Rata-rata pertambahan bobot badan per ekor per minggu dihitung dari selisih bobot badan per ekor pada akhir minggu dikurangi rataan bobot badan per ekor pada awal minggu di bagi tujuh hari.

Tabel 2. Pertambahan bobot badan ternak itik

\begin{tabular}{ll}
\hline Perlakuan & $\begin{array}{l}\text { Rata-rata } \\
\text { (gram/ekor/hari) }\end{array}$ \\
\hline P0 & $23,3 \pm 4,93$ \\
P1 & $27,08 \pm 14,35$ \\
P2 & $21,50 \pm 13,68$ \\
\hline
\end{tabular}

Berdasarkan hasil analisis ragam menunjukan bahwa perlakuan pakan tidak berbeda nyata $(P>0,05)$ terhadap pertambahan bobot badan harian ternak itik. Hasil penelitian menunjukan bahwa pertambahan bobot badan rata-rata perhari ternak itik umur delapan minggu adalah 24,14 gram /ekor /hari. Hasil penelitian ini menunjukan bahwa pertambahan bobot badan terendah berada pada perlakuan $\mathrm{P}_{2}$ yaitu 21,50 gram /ekor /hari. Perlakuan $P_{0} ; P_{1}$ dan $P_{2}$ memiliki rataan pertambahan bobot badan rata-rata harian yang tidak berbeda nyata. Hasil penelitian ini menunjukan bahwa 
Agrisaintifika

Jurnal Ilmu-Ilmu Pertanian

Vol. 5, No. 2, 2021

ransum ternak itik pengemukan tidak harus mengandung protein yang sangat tinggi di mana ransum dengan kandungan nutrisi 15\% sudah mampu memberikan tambahan bobot badan harian yang cukup baik.

Rataan PBB yang diperoleh dalam penelitian ini tergolong tinggi bila dibandingkan dengan hasil penelitian lainnya. Ketaren Dan Prasetyo (2001) melaporkan bahwa rataan PBB itik Mojosari Alabio umur 8 minggu sebesar 22,5 gram /ekor /hari. Menurut Iskandar et al. (2001) juga telah melaporkan bahwa rataan PBB itik jantan lokal dengan pemberian $20 \%$ ikan rucah + $80 \%$ dedak padi pada umur 2-10 minggu sebesar 20,321 gram /ekor /hari.

Menurut hasil penelitian Dapawole dan Sudarma (2020) bahwa rata-rata penambahan bobot badan harian adalah 22,5 gram/ ekor /hari menunjukkan bahwa ransum ternak itik penggemukan tidak harus mengandung protein yang sangat tinggi hingga $18 \%$ dimana ransum dengan kandungan nutrisi $12 \%$ sudah mampu memberikan tambahan bobot badan rata-rata harian yang cukup baik selama proses pemeliharaan 2-10 minggu. Hasil penelitian yang sama juga diperlihatkan oleh Randa (2007) bahwa hasil Rataan PBB itik Cihateup jantan dengan penambahan vitamin $\mathrm{E}$ dan vitamin $C$ dalam ransum pada umur 10 minggu sebesar 22,20 gram /ekor /hari. Fenomena ini kemungkinan besar disebabkan oleh perbedaan jenis ternak, jenis dan komposisi maupun nutrien yang terkandung dalam pakan penyusun ransum.

\section{Konversi}

Konversi ransum diperoleh dengan menghitung perbandingan antara jumlah pakan yang dikonsumsi dengan pertambahan bobot badan selama 8 minggu.

Hasil penelitian menunjukan konversi ransum harian ternak itik yang di beri pakan perlakuan $\mathrm{P}_{2}$ (pakan konsentrat buatan 100\%) memiliki nilai konversi tertinggi yaitu 6,63 , sedangkan perlakuan $\mathrm{P}_{1}$ (pakan konsentrat buatan 50\% dan BR2 50\%) memiliki nilai konversi 5,52 dan perlakuan $\mathrm{P}_{0}$ (pakan konsentrat $\mathrm{BR}_{2} 100 \%$ ) memiliki nilai konversi terbaik yaitu 4,85 .

Tabel 3 . Rata-rata konversi ransum ternak itik

\begin{tabular}{ll} 
Perlakuan & Rata-rata \\
\hline P0 & $4,85 \pm 0,646^{\mathrm{a}}$ \\
P1 & $5,52 \pm 0,432^{\mathrm{b}}$ \\
P2 & $6,63 \pm 0,308^{\mathrm{c}}$ \\
\hline
\end{tabular}

Keterangan : superskrip dengan huruf yang berbeda pada kolom yang sama menunjukkan perbedaan nyata $(P<0,05)$

Berdasarkan hasil analisis ragam menunjukan bahwa pakan perlakuan berpengaruh nyata $(P<0,05)$ terhadap konversi ransum ternak itik. Hal ini dimungkinkan karena tingkat palatabiltas dan konsumsi ransum di setiap perlakuan yang berbeda. Konversi ransum paling tinggi berada pada perlakuan $\mathrm{P}_{2} \quad 6,63$ yang menunjukan bahwa ransum $P_{2}$ kurang di anjurkan untuk di gunakan sebagai ransum itik ternak itik apabila hanya melihat dari faktor tingkat konversi ransum.

Konversi ransum paling rendah berada pada perlakuan $\mathrm{P}_{1}$ dan $\mathrm{P}_{0}$ yaitu 5,52 dan 4,85 sehingga dapat menjadi rekomendasi ransum ternak itik apabila hanya dinilai dari tingkatan konversi ransum saja. Hasil penelitian koversi ransum ini masih jauh lebih baik di bandingkan dengan hasil penelitan Purba dan Ketaren (2011) yang memperlihatkan konversi ransum sebesar $5,03 \pm 0,06$ hingga $5,35 \pm 0,05$.

Iskandar et al. (2011) juga memperlihatkan adanya rataan konversi ransum yang tinggi pada pada itik mojosari yakni sebesar 6,59 yang di berikan ransum $20 \%$ ikan runcah dan $80 \%$ dedak. Konversi ransum yang berbeda ini menunjukan adanya perbedaan yang cukup tinggi jika ransum di buat dari jenis bahan baku yang berbeda. Ransum $\mathrm{P}_{0}$ dan $\mathrm{P}_{1}$ dapat di jadikan ransum komplit ternak itik pengemukan yang menawarkan nilai konversi yang rendah. 
Agrisaintifika

Jurnal Ilmu-Ilmu Pertanian

Vol. 5, No. 2, 2021

Sudarma, et al. 2021

Hasil penelitian Ketaren (2006) melaporkan bahwa FCR (Feed Conversion Rate) itik Serati dengan pemberian polar level 30, 40 dan 50\% masing-masing sebesar $(3,42),(3,39)$ dan $(3,47)$, sedangkan konsumsi pakan dengan level polar yang sama masingmasing sebesar (6059), (6190) dan (6111) gram /ekor selama 8 minggu. Penggunaan pakan yang tidak efisien pada itik petelur maupun pedaging menurut Ketaren (2007) dapat diakibatkan oleh berbagai faktor yaitu: faktor genetik/bibit, banyaknya pakan tercecer dan kandungan gizi pakan yang tidak sesuai kebutuhan.

Tabel 4. Perhitungan ekonomis

\begin{tabular}{llll}
\hline Perlakuan & $\begin{array}{l}\text { Konversi } \\
\text { ransum }\end{array}$ & $\begin{array}{l}\text { Harga } \\
\text { pakan/kg } \\
(\mathrm{Rp})\end{array}$ & $\begin{array}{l}\text { Harga } \\
\text { pakan/kg } \\
\text { daging }(\mathrm{Rp})\end{array}$ \\
\hline $\mathrm{P}_{0}$ & 4,85 & 10.000 & 48.500 \\
$\mathrm{P}_{1}$ & 5,52 & 7.063 & 38.985 \\
$\mathrm{P}_{2}$ & 6,63 & 4125 & 27.349 \\
\hline
\end{tabular}

Berdasarkan tabel 4 diatas, hasil perhitungan menunjukan konversi ransum yang memiliki nilai terbaik diperoleh pada perlakuan $\mathrm{P}_{0}$ (pakan komersial $\mathrm{BR}_{2}$ ) yaitu 4,85. Namun untuk menghasilkan satu kilo bobot badan, pada perlakua $\mathrm{P}_{0}$ membutuhkan biaya yang sangat tinggi sebesar Rp 48.500. hal ini justru berbanding terbalik dengan perlakuan $\mathrm{P}_{2}$ (pakan konsentrat buatan) yang memiliki nilai konversi ransum yang kurang baik yaitu 6,63 namun mampu menghasilkan satu kilo bobot badan dengan biaya yang sangat ekonomis yaitu Rp 27.349.

Berdasarkan perhitungan ekonomis harga ransum yang jauh lebih murah pada ransum $\mathrm{P}_{2}(\mathrm{Rp} 4.125 / \mathrm{kg})$ dibandingkan ransum $\mathrm{P}_{0}(\mathrm{Rp}$ $10.000 / \mathrm{kg}$ ) maka ransum $P_{2}$ dapat dijadikan alternatif ransum penggemukan ternak itik dengan perbandingan biaya ransum hanya $R p$ 27.349 untuk menghasilkan pertambahan $1 \mathrm{~kg}$ bobot hidup ternak itik.

\section{SIMPULAN}

Pakan konsentrat buatan $\left(\mathrm{P}_{2}\right)$ dapat mengantikan pakan komersial $\mathrm{BR}_{2}$ hingga $100 \%$ pada ternak itik dengan bobot badan umur 10 minggu 1.497 gram /ekor /hari, pertambahan bobot badan harian 21,50 gram lekor /hari, dan nilai konversi ransum 6,63 serta memiliki nilai ekonomis yang paling ekonomis Rp 27.349/kg bobot hidup.

\section{DAFTAR PUSTAKA}

Ambara, A. A., I. N. Suparta, dan I. M. Suasta.2013. Performan itik cili (persilangan itik peking $\mathrm{x}$ itik bali) umur

1-9 minggu yang diberiransum komersial dan buatan dibandingkan itik bali. Peternakan Tropika, 1. (1) : 20-33.

Anggraini, A.D., 1, Poernama, F., Hanim, C., dan Dono, N.D. 2017. Penggunaan protease dalam pakan yang menggunakan limbah pertanian peternakan untuk meningkatkan kinerja pertumbuhan ayam broiler. Buletin Peternakan, 41 (3) : 243-249.

Dapawole R. R dan Sudarma. I. M. A 2020. Pengaruh pemberian level protein berbeda terhadap performs produksi itik umur 2-10 minggu diSumba Timur.Program studi peternakan Universitas Kristen Wira Wacana Sumba. Vol. 15. Hal. 320-326.

Dinas Peternakan NTT. 2016. Statistik Pertanian Provinsi Nusa Tenggara Timur. Badan Pusat Statistik NTT.

Iskandar, S., Vanvan S. Nugroho, D. M. Suci and A. R. Setioko. 2001. Adaptasi Biologis Itik Jantan Muda Lokal terhadap Ransum Berkadar Dedak Padi Tinggi. Pros. Lokakarya Unggas Air. Pengembangan Agribisnis Unggas Air sebagai Peluang Usaha Baru. Ciawi, 5-6 Agustus 2001. Fakultas Peternakan IPB Bogor-Balai Penelitian Ternak. Bogor. hlm. 118-127.

Ketaren, P. P dan L. H. Prasetyo. 2001. Pengaruh Pemberian Pakan Terbatas Terhadap Penampilan Itik Silang Mojosari x Alabio (MA) Umur 8 Minggu. 
Agrisaintifika

Jurnal Ilmu-Ilmu Pertanian

Vol. 5, No. 2, 2021

Sudarma, et al. 2021

Pros. Lokakarya Unggas

Air.Pengembangan Agribisnis Unggas

Air Sebagai Peluang Usaha Baru.

Ciawi, 56 Agustus 2001. Fakultas

Peternakan IP B Bogor-Balai Penelitian

Ternak, Bogor. HIm. 105-110.

Ketaren, P. P. 2006. Pengaruh Suplementasi

Enzim ke dalam Pakan

Mengandung Dedak Tinggi terhadap

Performan Itik Pedaging. Pros. Seminar Nasional Bioteknologi. Cibinong, 15 16 Nopember 2006. Puslit Bioteknologi, LIPI, Cibinong. hlm. $134-139$.

Ketaren, P.P. 2007. Peran Itik sebagai Penghasil Telur dan Daging Nasional. Wartazoa, (17) : 117 - 127

N R C. 1994. Nutrient Requirement of Poultry. Ninth Revised Edition. Printing and Publishing National Academy of Science. Washington.

Prasetyo, L.H., P.P. Ketaren, P.S. Hardjosworo. 2005. Perkembangan teknologi budidaya itik di Indonesia. Lokakarya Nasional Unggas Air II. Di dalam: Merebut peluang agribisnis melalui pengembangan usaha kecil dan menengah unggas air.
Prosiding Kerjasama Balai Penelitian Ternak, Pusat Penelitian dan Pengembangan Peternakan, Masyarakat Ilmu Perunggasan Indonesia (MIPI) dan Fakultas Peternakan IPB. Bogor, 16-17 Nopember 2005. Ciawi, Bogor. hal : 145161.

Purba, dan Ketaren, P . P. 2011. Konsumsi dan Konversi Pakan Itik Lokal Jantan Umur Delapan Minggu dengan Penambahan Santoquin dan Vitamin $\mathrm{E}$ dalam Pakan. JITV, 16. (4): 280-287.

Puvanendran V, DL.B, Brown J. 2003. Food rationrequirements of $0+$ yellowtail flounder Limanda ferruginea (Storer) juveniles. Aquaculture. 220:459-475.

Randa, S.Y. 2007. Bau Daging Dan Performa Itik Akibat Pengaruh Perbedaan Galur Dan Jenis Lemak Serta Kombinasi Komposisi Antioksidan (Vitamin A, C, Dan E) Dalam Pakan. Disertasi. Fakultas Peternakan, Institut Pertanian Bogor, Bogor.

Stansfield, W.E. 1983. Theory and Problems of Genetics. 2 ${ }^{\text {nd }}$ Ed. Mc Graw Hill Book Company Inc, New York. 